\title{
FEATURE Mississippi River threatens to make Dogtooth Bend peninsula in Illinois an island
}

\author{
Kenneth R. Olson and Lois Wright Morton
}

$\mathrm{T}$ he receding floodwaters of the Mississippi River in January of 2016 left behind barren sand dunes on southern Illinois farmland reminiscent of the windswept dunes of the movie Lawrence of Arabia (figure 1). Large sand deposits up

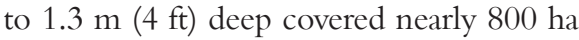
$(2,000 \mathrm{ac})$ of farmland south of Miller City, Illinois, in the Dogtooth Bend peninsula. Rainfall almost three times above average in November and December of 2015 over Missouri set in motion record flooding with the Cape Girardeau river gage breaking the 1993 record at $14.89 \mathrm{~m}(48.86 \mathrm{ft})$ and led to the breaching of Len Small levee on January 2, 2016. Floodwaters cut deep craters and scoured the landscape as they poured through the breach at mile marker 34 and then followed an old meander channel across the narrow neck of Dogtooth Bend peninsula to reconnect with the Mississippi River at mile marker 15 (figure 2). Levee breaches and land scouring are not new events for this region, occurring in 1993, 2011, and 2016; and there is high likelihood these farmlands will experience similar events in the future. Each event deepens the meander channel when the floodwaters take a $4.6 \mathrm{~km}(3.5$ mi) shortcut and threaten to permanently reroute the Mississippi River leaving Dogtooth Bend peninsula an island. This would result in landowners and farmers of 6,000 ha $(15,000 \mathrm{ac})$ in the Dogtooth Bend area no longer having road access to their land if the Mississippi River realigns naturally. In some cases the land use would likely shift from agriculture to other uses.

\section{HISTORY OF FLOODING OF THE DOGTOOTH BEND PENINSULA IN SOUTHWEST ILLINOIS}

The Mississippi River has a long history of continually changing course. After the

Kenneth R. Olson is professor emeritus of soil science in the College of Agricultural, Consumer, and Environmental Sciences, University of IIlinois, Urbana, Illinois. Lois Wright Morton is professor of sociology, College of Agriculture and Life Sciences, lowa State University, Ames lowa.

\section{Figure 1}

Mississippi River floodwaters deposited many tons of sand on farmland and roads in Dogtooth Bend peninsula when the Len Small levee breached in January of 2016. The sand dunes left behind required graders and snow plows to open the road for local traffic.

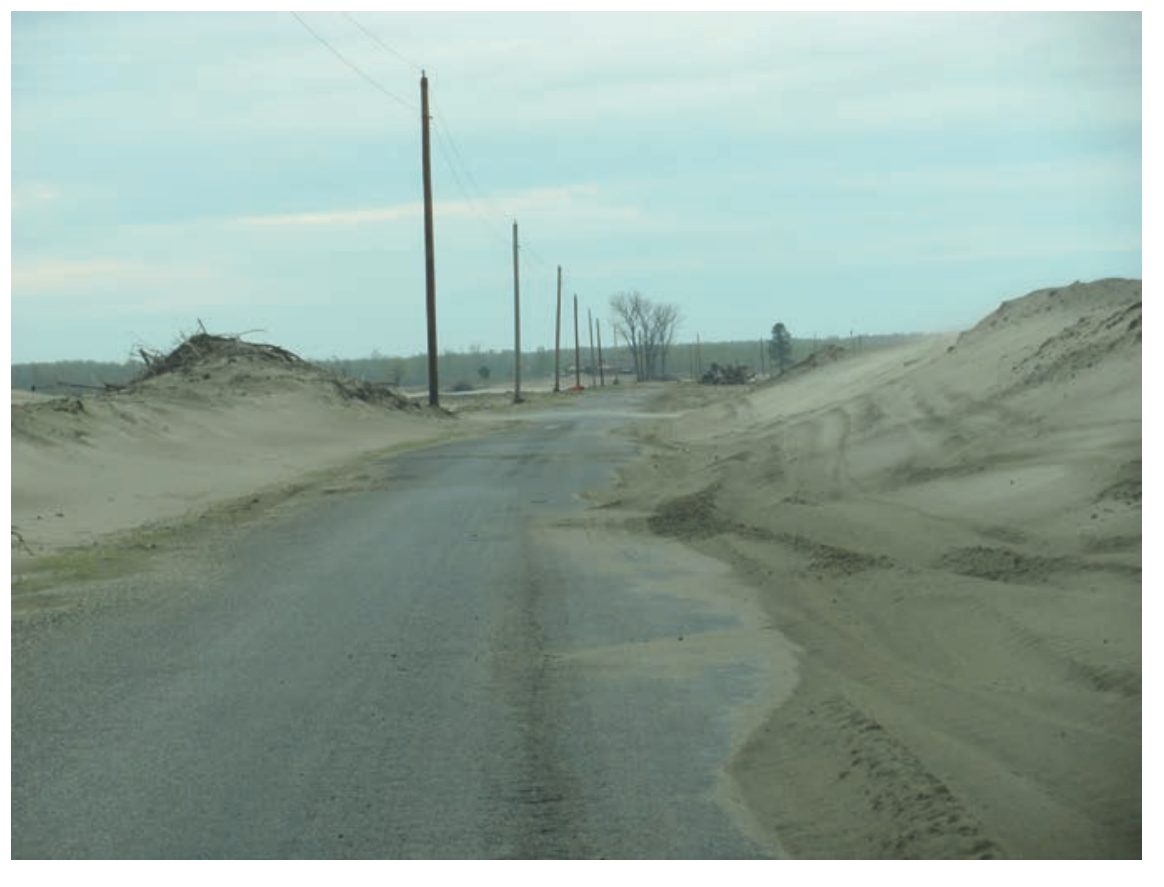

last glacier advance at the end of the Great Ice Age, the melting ice waters flooded and altered the flow of many channels and streams including the ancient Mississippi and ancient Ohio rivers. The middle Mississippi Indians in the fourteenth and fifteenth centuries built two ceremonial mounds and a village near Milligan Lake (Maruszak 1977) at an elevation of 100 m (328 ft) in the area of Dogtooth Bend peninsula (figure 2) along a waterway or meander channel of the Mississippi River

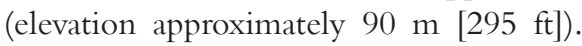
This suggests that humans lived here for more than 700 years and the area was seldom flooded.

However, the farmers and homeowners who settled in early 1800s on the bottomlands of southwest Alexander County, locally known as Dogtooth Bend peninsula, have battled flooding from the Mississippi River for the last 200 years. Illinois became a state in 1818 , and
Alexander County was established on March 4, 1819. Farming of the Mississippi and Ohio bottomlands started in the 1840s and depending on location continues to present day. Flooding in those early years was less of a problem since only corn (Zea mays L.), oats (Avena sativa L.), and soybean (Glycine max [L.] Merr.; after 1930s) were grown during the summer growing season. There was very little winter wheat (Triticum aestivum L.) as it would be vulnerable to early spring or late fall flooding.

In the 1880s the Missouri farmers on the west side the Mississippi River south of Commerce, Missouri (figure 3), began constructing levees to protect their bottomlands. This redirected Mississippi River floodwaters toward southwest Alexander County, Illinois, where lands were not leveed. During this same period, Missouri farmers also built levees south of Cape Girardeau, Missouri, to block the Mississippi River during flood events from entering its ancient valley and flood- 


\section{Figure 2}

This map of the Dogtooth Bend area in southwest Illinois shows the 1993, 2011, and 2016 breach locations and the 2016 Mississippi River floodwater overland flow patterns. The blue dotted line represents a new channel cutting through southeast Alexander County and floodwaters flowing north of Lake Milligan and then exiting into the Mississippi River at mile marker 15.

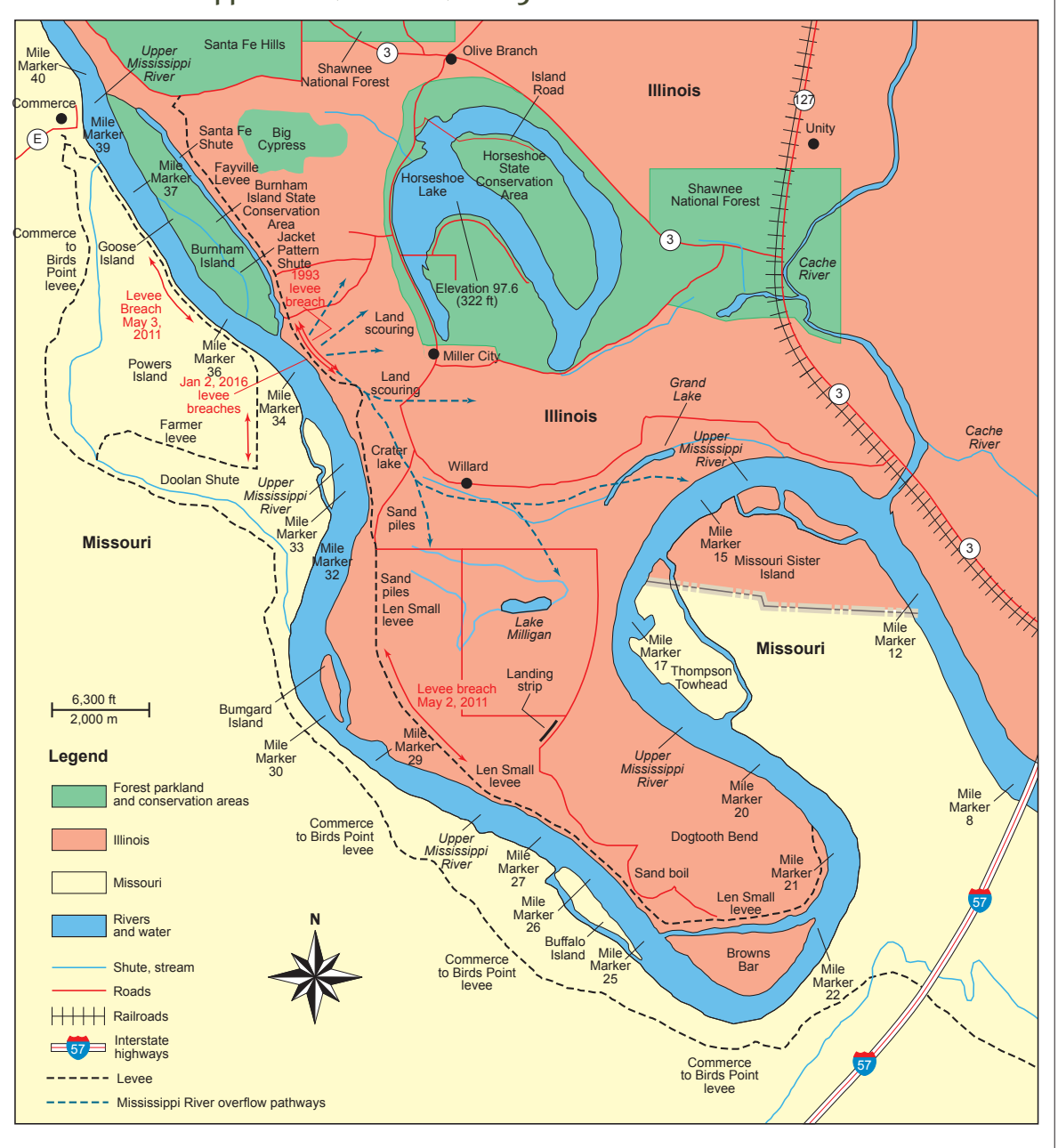

ing lands around the Big Swamp. The Alexander County, Illinois, bottomland farmers were likely not aware of how the Missouri farmer levees built between 1880 and 1915 (shown in figure 3 by thick black lines on the west side of the riverone south of Cape Girardeau and the other south of Commerce) might affect the Illinois lands on the east side of the Mississippi River.

After the $74 \mathrm{~km}$ (46 mi) Little River Drainage District Headwaters project diversion levee and channel was constructed in 1916, the runoff from the 288,000 ha $(720,000$ ac) Ozark Plateau via the Castor and Whitewater rivers and Crooked Creek was diverted into the Mississippi River north of the Thebes
Gap and south of Cape Girardeau (figure 3) (Olson and Morton 2016a). Prior to the creation of the diversion channel, the Ozark Plateau waters entered the Mississippi River north of Helena, Arkansas, more than 365 river miles to the south (Olson and Morton 2016b) The Little River Headwaters Diversion levee and channel effectively raised the floodwater peaks recorded on the river gages at Cape Girardeau, Missouri; Thebes in Alexander County, Illinois; Cairo, Illinois; and Hickman, Kentucky. New floodwalls and levee systems were built to address threats of urban floodingCairo, Illinois, in 1928; the New Madrid Floodway, Missouri, from 1928 to 1932; and Cape Girardeau, Missouri, between
1956 and 1964 (Olson and Morton 2016c). To reduce agricultural land flooding, the Hickman levee (Kentucky) was strengthened, the Missouri levees south of Commerce were aggressively maintained, and a new federal levee was created from Commerce to Birds Point, Missouri, which connected to the New Madrid Floodway setback levee (Olson and Morton 2012; Olson and Morton 2016b).

Between the 1840s and 1943 the Alexander County bottomland farmers were not protected from Mississippi River floodwaters. There is little historical evidence that the Illinois farmers and landowners were aware of the impact on river height from creating the $72 \mathrm{~km}$ (45 mi) Little River Drainage District Headwaters Diversion (in the year 1916) (Olson and Morton 2016a, 2016b, 2016c) or the construction of additional levees on the west side of the river. However, the Dogtooth Bend area at $10 \mathrm{~m}$ (33 ft) above the Mississippi River began to experience more frequent flooding and water flowing into old meander channels as the river reached greater peak heights during flood events.

\section{LEN SMALL LEVEE AND DRAINAGE DISTRICT}

By 1940, it was apparent to Illinois landowners that they needed to protect their farms and homes from river flooding, and they created the Len Small Levee and Drainage District (LSLDD) in the Dogtooth Bend area (1943) and later the Fayville levee extension in 1969 (figure 2). The new farmer drainage district built a sand core levee, which was lower and weaker than Missouri and Kentucky farmer and mainline federal levees near the confluence of the Mississippi and Ohio rivers. With the construction of LSLDD levees, the Mississippi River was now confined by levees on both sides to a less than $2.5 \mathrm{~km}$ (1.5 mi) wide corridor from Commerce, Missouri, at mile marker 39 to mile marker 15. This reduction in the original Mississippi River floodplain which was six times wider than the new corridor, meant the loss of considerable space for storing flood waters and resulted in increased peak heights during major flooding events (figure 2). However, during the first 50 years, 


\section{Figure 3}

This map shows the location of the Missouri Little River Drainage District diversion channel outlet below Cape Girardeau and the Missouri and Illinois farmer levees south of the Thebes Gap and Commerce, Missouri, which narrowed the original 16 $\mathrm{km}$ wide Mississippi River floodplain to less than $2 \mathrm{~km}$.

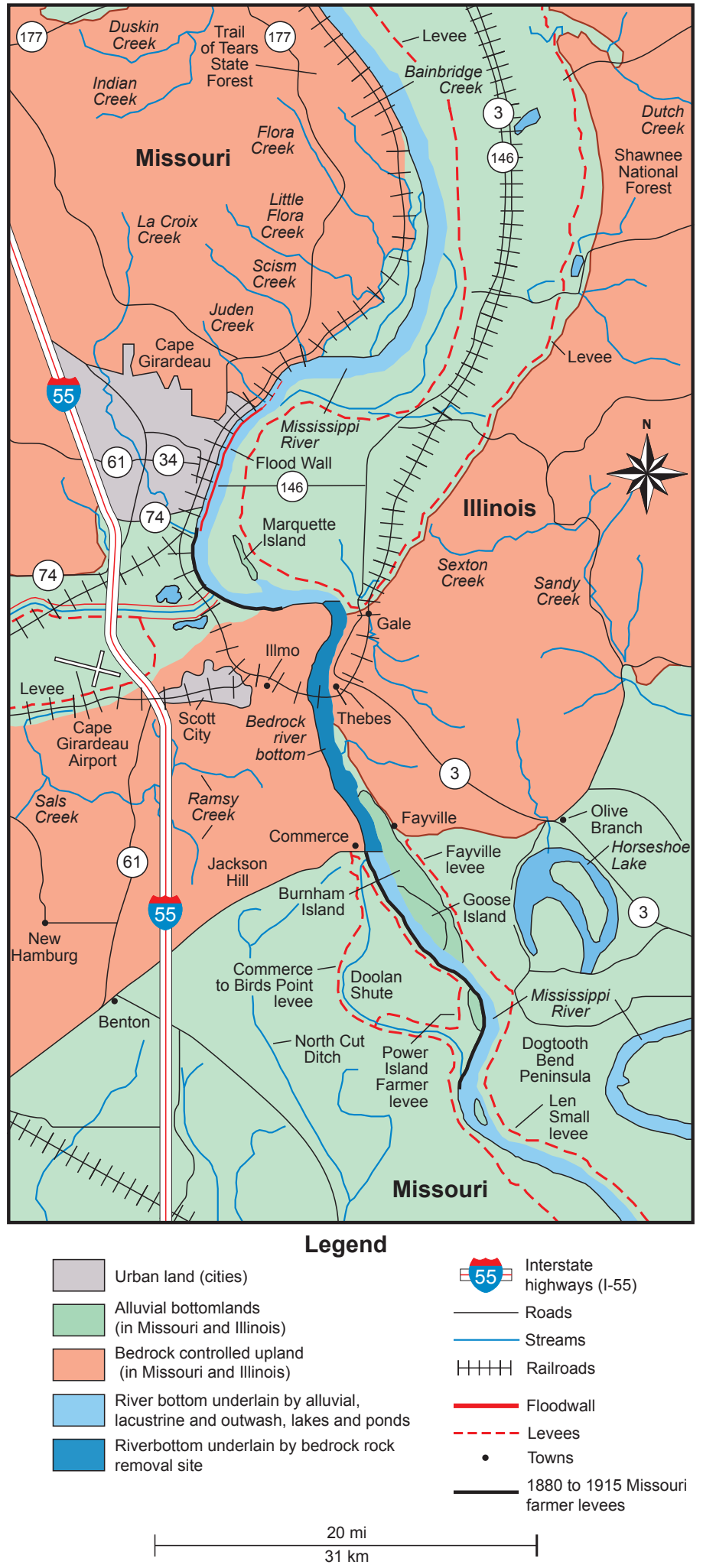

from 1943 to 1993, no documented Len Small breach occurred.

Then, in 1993, the Len Small-Fayville levee failed when the Mississippi River reached record heights and was repaired. It failed again in 2011, with breaches and craters in five places. The largest 2011 breach was repaired when LSLDD pushed sand into the levee hole, making a sand core barrier between the river and farmland, which the US Army Corps of Engineers (USACE) in 2012 covered with a clay cap at a cost of US $\$ 5$ million. This was the second known federal involvement in building or repairing the Len Small farmer levee. The 1993 and 2011 levee breaches resulted in the flooding of 6,800 to 14,000 ha $(17,000$ to 35,000 ac) with an unknown number of buildings damaged and removed after the 1993 flood and 169 structures damaged during the 2011 flood. The Federal Emergency Management Agency awarded the State of Illinois an US\$8.7 million grant that required a state match to purchase these structures beginning in April of 2015, but only a few homes were purchased before July 1, 2015. After the Illinois legislature failed to pass a state budget in July of 2015, the state matching funds were not available and the program could not be fully implement before the 2016 flood.

\section{FLOOD OF 2016}

The 2016 Len Small levee breach was much more severe than 2011 because of its location (figure 2). The fast moving river cut a $1.6 \mathrm{~km}(1 \mathrm{mi})$ long breach during late December of 2015 through early January of 2016 (figure 4) and scoured out a crater lake and deep gullies into adjacent agricultural lands. The southeast flow of the Mississippi River floodwaters through the breach created a new channel (figure 5) from river mile marker 34 through Alexander County, connected to an old meander channel, and then exited back into the main stem river at mile marker 15 , a distance of $4.6 \mathrm{~km}$ (3.5 mi). This shortcut across Dogtooth Bend peninsula by-passed about 15 river miles $(24 \mathrm{~km})$ of the current Mississippi River path (figure 2). Approximately seven river lane-line buoys, hundreds of trees (figure 6), irrigation pivots, and other debris were carried onto 
the Dogtooth Bend bottomlands along with millions of tons of sand deposited on more than 600 ha $(1,500 \mathrm{ac})$ of farmland. Another 800 ha $(2,000 \mathrm{ac})$ were subjected to land scouring by the Mississippi floodwaters. The county lost 11 to $13 \mathrm{~km}$ (7 to $8 \mathrm{mi}$ ) of roads with others buried by sand (figure 1). After ditches and culverts filled with sand, drainage was nearly impossible.

The LSLDD staff members (Jim Taflinger, personal communication, April $15,2016)$ were pessimistic that the district had sufficient resources to repair the levee, fill the crater lake extending $1 \mathrm{~km}$ (0.6 mi) through the levee, and fill and regrade the $2 \mathrm{~km}(1.3 \mathrm{mi})$ channel created by the 1993 levee breach and the 2011 deepening of the old meander channel north of Lake Milligan to mile marker 15. It is currently not clear what actions the USACE will take and what resources they have to support the LSLDD repair of the Len Small-Fayville levee. A damage assessment including both a land scouring and sand depositional survey and an updated soil survey (conducted by the USDA Natural Resource Conservation Service [NRCS]) of the 6,800 ha $(17,000$ ac) of LSLDD land and perhaps a total of 14,000 ha $(35,000 \mathrm{ac})$ of southwest Alexander County covered by floodwaters is needed.This information is necessary to guide current repair decisions and evaluate alternative investments and activities in preparation for future flooding. Until repairs to the levee breach are made, the Alexander County bottomlands are totally exposed to the next Mississippi River flooding event.

Following the January of 2016 winter flood, the USACE moved a large amount of rock in front of the 1,200 m (4,000 ft) breach (figure 4) in anticipation of spring floods to keep the Mississippi River from extending the $4.6 \mathrm{~km}$ (3.5 mi) channel to the next downstream bend in the Mississippi River. If the channel were to permanently cross Dogtooth Bend peninsula, it would become an island cutting off more than 6,000 ha $(15,000 \mathrm{ac})$, at least one hunting structure, and one home from the Illinois mainland. The USACE conducted a sonar survey of the 2016 Len Small levee breach to identify craters, holes, scouring and the extent of damage. The flooding took out

\section{Figure 4}

The 2016 Len Small levee breach was 1.6 km long. US Army Corps of Engineer crews, working from barges in the Mississippi River channel, dropped rocks in front of and against levee banks in an attempt to stabilize them. This rock barrier covering a portion of the south end of the levee breach is shown in the right side of picture.

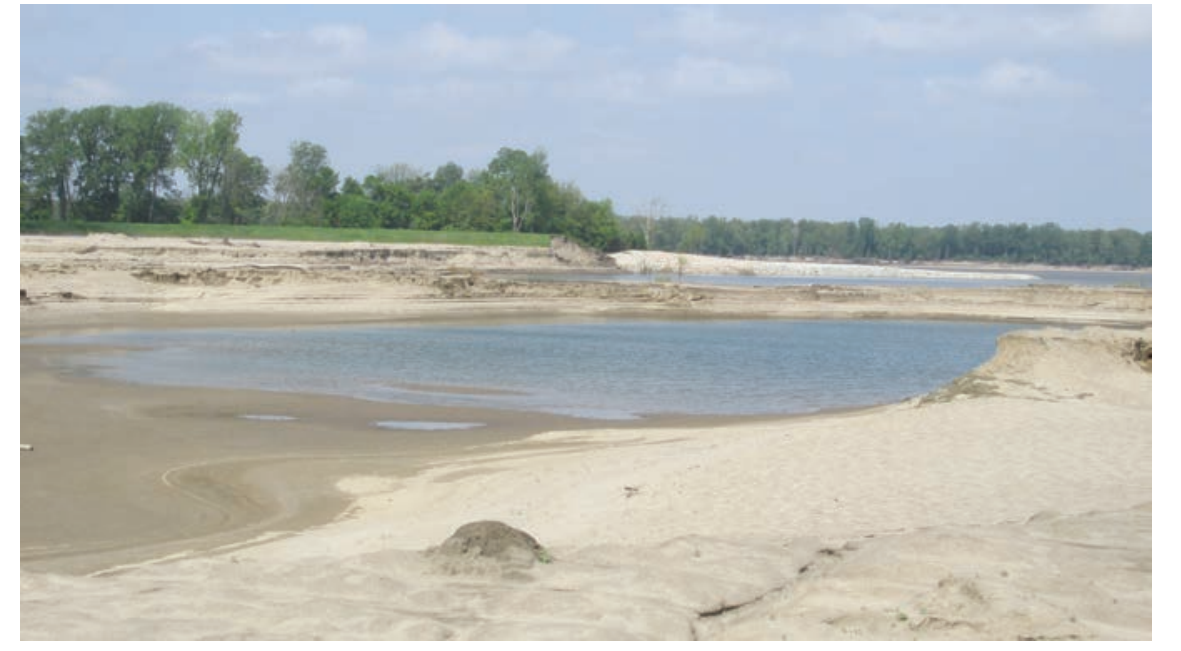

tree lines and wiped out large chunks of the levee with sonar revealing scouring of soil and underlying parent material as deep as 9 m (30 ft) according to Alexander County engineer Jeff Denny (personal communication, April 20, 2016). However, the sonar survey showed the damage could have been much worse, finding the damaged area was not as large as in 1993.

\section{REPAIR AND RESTORATION EFFORTS POST-2016 LEN SMALL LEVEE BREACH}

The USACE sonar survey helped the LSLDD to prioritize repairs and target restoration efforts. However local, state, and federal financial resources were limited, and many important repairs were put on hold until resources were available. After farmers, homeowners, and county crews worked to make sure their homes were safe, farmers turned to the spring work of preparing fields for planting. By April some landowners had begun removing the sand from their fields or incorporating it into the topsoil with a combination chisel plow and disk (figure 7). Some soybeans were planted by late April in fields with thin sediment deposits.

However, by August of 2016, nearly eight months after the breach, the levee still had a gaping hole, and many repairs had not yet occurred.Without repairs to the levee breach, there was little value in fixing the roads, in cleaning out the ditches, or moving the sand off fields; and planting crops was risky. Spring or summer floodwaters could again pour through the hole, drowning crops and covering roads, ditches, and fields with new sand and debris. Delayed planting reduced crop yield potential, and much of the 2016 harvest was at risk. This was not a new experience for farmers in the Mississippi and Ohio river confluence area. Back in 2011, New Madrid Floodway farmers (Missouri) planted 24,000 ha $(90,000 \mathrm{ac})$ of soybeans from June 15 to July 7 and experienced modest yield reductions (Olson and Morton 2012, 2013). However, 12,000 ha $(30,000 \mathrm{ac})$ were not planted that year (2011) in the New Madrid Floodway. The same year, 140 New Madrid Floodway farmers sued the USACE when major flooding damaged (land scouring, crater lake, gully fields, and sand deposition) their land. Alexander County farmers are part of this familiar debate about farmland in the floodplain and who is responsible for its protection.

\section{POST-2016 AND FUTURE ALTERNATIVES}

Dogtooth Bend farmers and landowners, members and staff of the LSLDD, community and state-level leaders, and the USACE have some difficult decisions ahead in repairing the current landscape and in preparing for future flood events that predispose the Mississippi River to 


\section{Figure 5}

A close-up map of the $\mathbf{2 0 1 6}$ Len Small levee breach on the Mississippi River from mile marker 34 to 30 . Floodwaters poured through the breach depositing sand over a large part of the area and created the new channel shown on the map (yellow area).

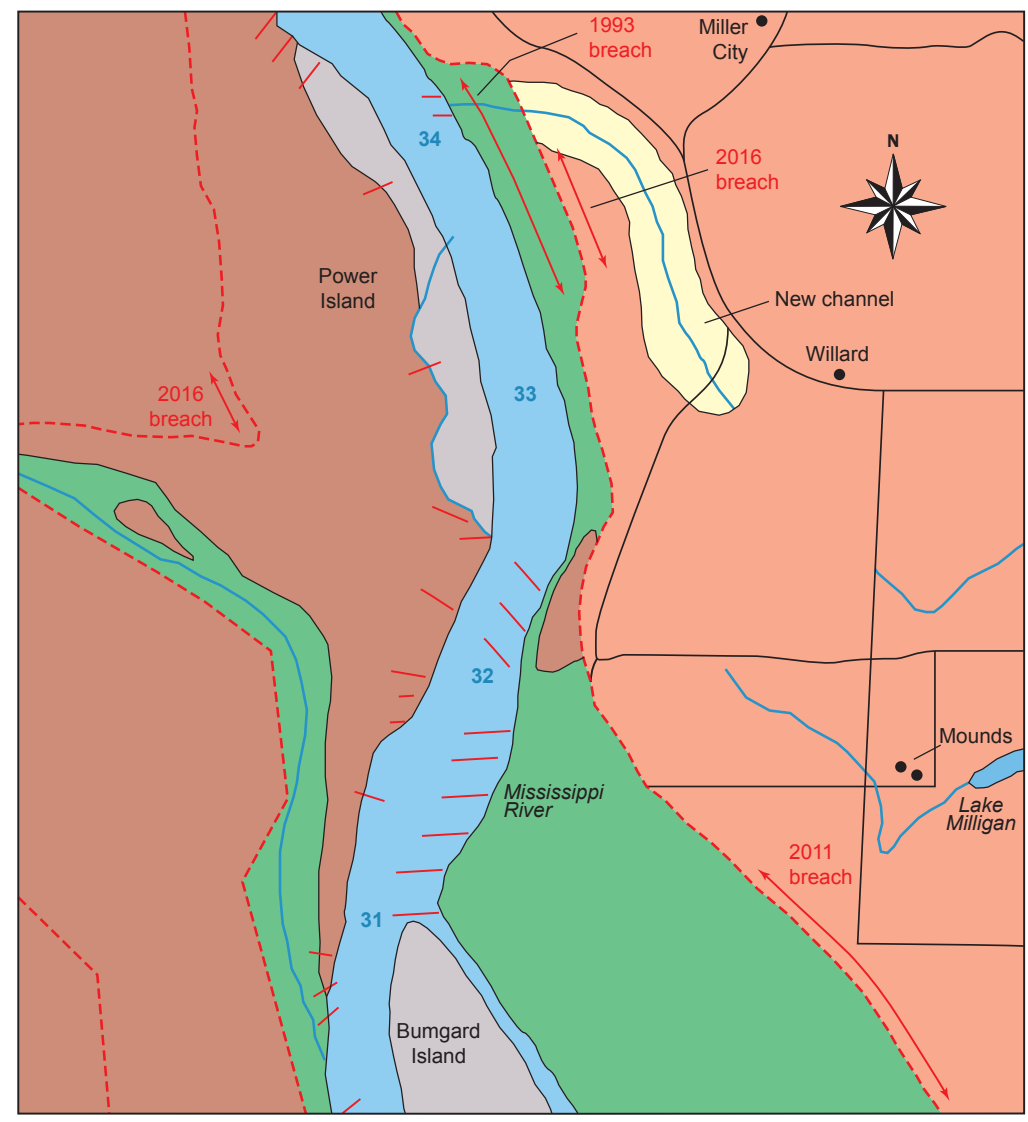

Legend

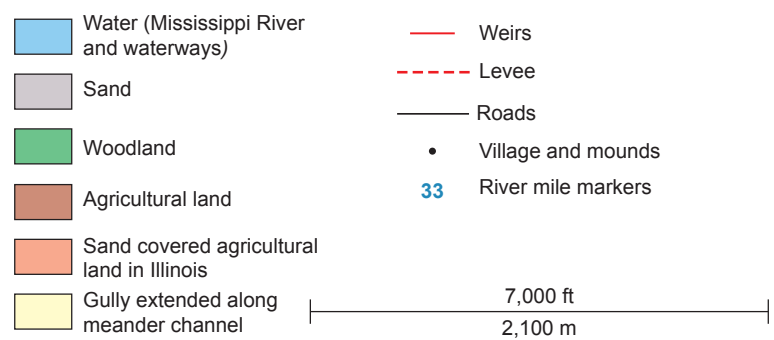

realign and create a new flow path across Dogtooth Bend peninsula. These decisions affect future land uses, resource allocations, and the livelihoods of the people of southern Illinois.

Agriculture is currently the primary land use in this area. There is a need for an updated county soil survey by USDA NRCS that assesses gully formation locations, soil erosion, sediment deposition damages, and land uses. The most recent soil survey of Alexander County (Williams et al.2007) is almost 10 years old, with two decreased (Olson and Morton 2015), and these changes in land use affect land values. Without an updated soil survey of the Dogtooth Bend area, the land continues to be taxed as if no land scouring or sand deposition had occurred because land productivity indices are not adjusted to reflect the soil degradation, land scouring, or sand deposition. Further, longer term planning for existing and new land uses is hindered without sufficient information to evaluate investments in reclamation of farmland or nonfarm uses.

The Mississippi River Commission (MRC)/USACE and the LSLDD are partners in managing the river landscape and need to develop and evaluate alternative strategies for addressing the river-land relationships in the Dogtooth Bend area. Several alternative courses of action are presented in this paper. While many of the details of each alternative would need to be evaluated and negotiated, they offer a start in visioning different scenarios to guide preparation for the future.

The first alternative is to continue, as in the past, to repair the Len Small levee. This could impede and delay the eventual and natural tendency of the Mississippi to take a shortcut and realign its downstream course. This alternative is a near-term fix. There is a high likelihood at some future date that another flood event will occur, and the Len Small levee will breach again, creating new craters and gullies and flooding farmland. Since 1993, major weirs and bank stabilizing efforts along the Mississippi River banks in this area have been put in place three times. Although these structures have slowed the water and bank erosion, they have not prevented the breaches of 2011 and 2016 and are likely inadequate to deter levee damage during future high water events.

A second alternative is to proactively construct a diversion channel, with embankments on both sides, where the old meander channel is currently located. During high water periods, the channel would temporarily redirect excess Mississippi River floodwaters across the neck of Dogtooth Bend peninsula and allow the water to exit back into the river at mile marker 15. The existing Mississippi River $3 \mathrm{~m}$ (9 ft) channel between mile 


\section{Figure 6}

Hundreds of trees were transported by floodwaters and dropped on agricultural lands along with sand and lane line buoys like the red one shown here.

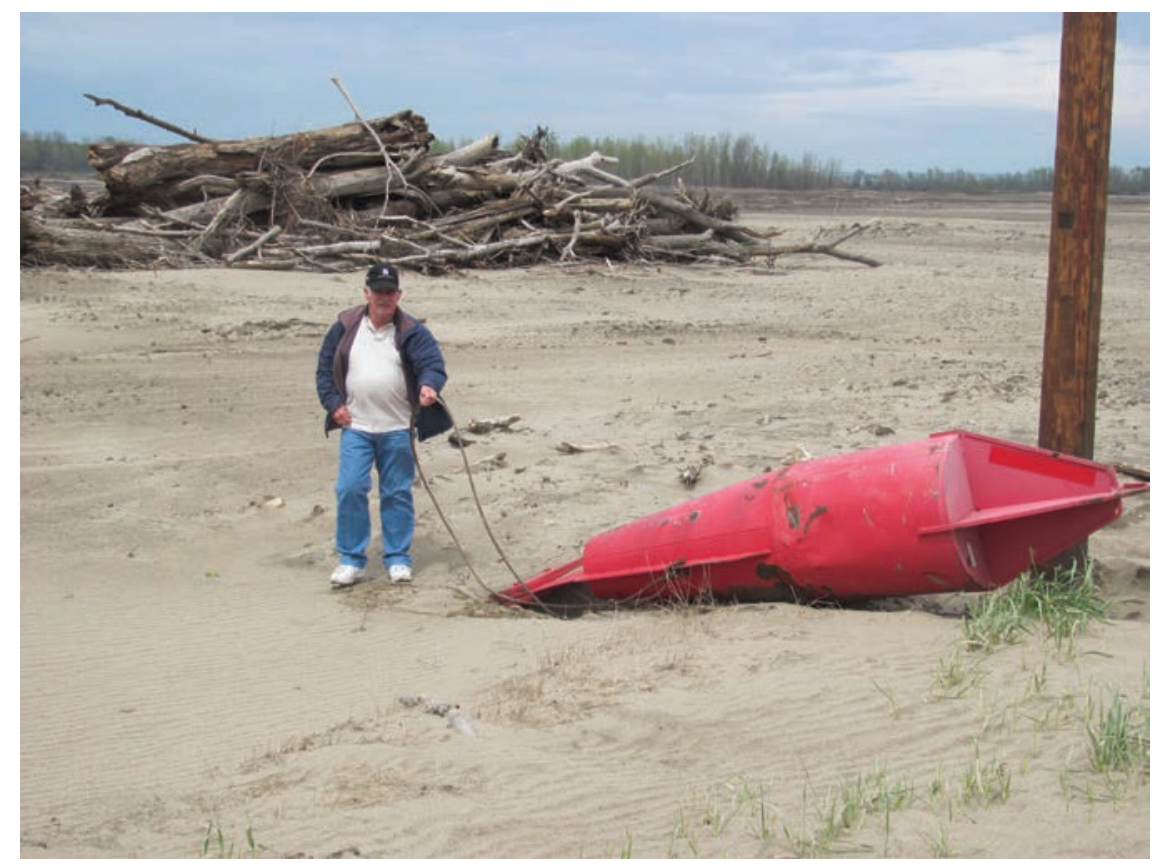

\section{Figure 7}

A combination chisel plow and disk is being used to incorporate the sand into the topsoil. The tillage equipment driver attempted to avoid the crater lake, gullies, and land scoured area.

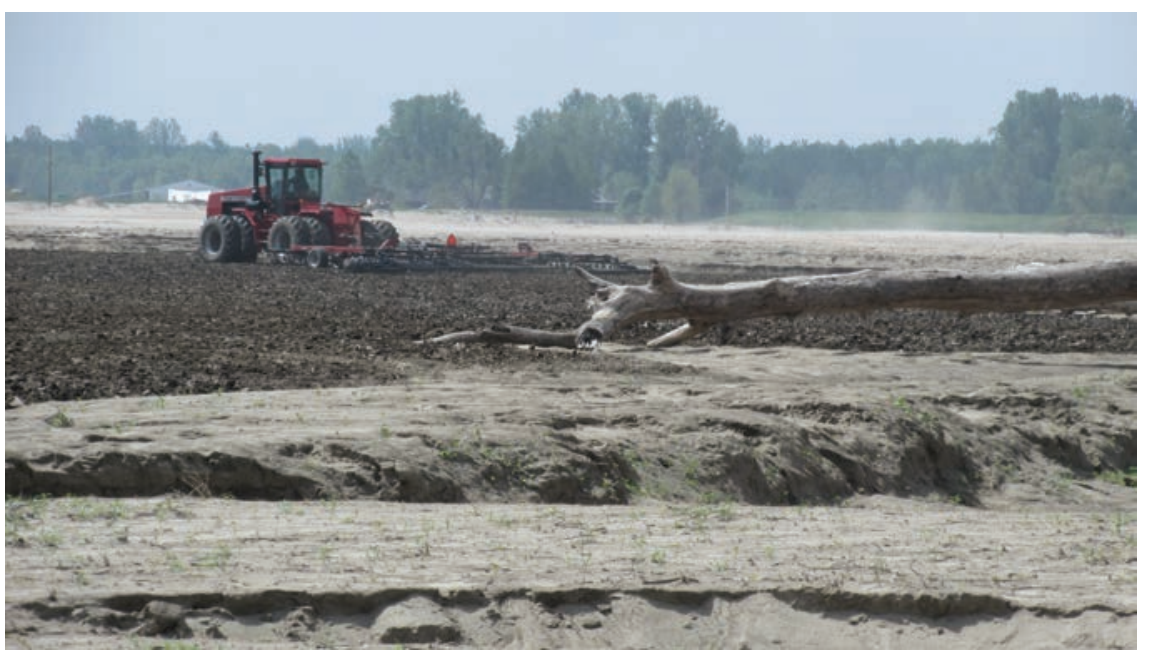

markers 34 and 15 would be maintained for navigation. One or more bridges would need to be built over the diversion channel to allow access to farmland, agricultural structures, and homes; and to recreational hunting, fishing, birdwatching uses. Hydrologic studies and environmental, economic, and social acceptability analyses would be necessary to fully evaluate the investments needed and impacts on the region.

A third alternative is to assist the Mississippi River realignment tendency and construct a $1 \mathrm{~km}$ (0.6 mi) wide new Mississippi River channel through the 4.6 $\mathrm{km}$ (3.5 mi) shortcut between mile marker
34 and 15 where the Mississippi River is already cutting with each major flooding event. The USACE could accelerate this process even more by making this channel between mile markers 34 and 15 the main stem river navigation channel. This would also require thorough hydrologic, environmental, social, and economic assessments.

An elaboration of the third alternative is to create a new Mississippi River channel with low rise levees on each side of the navigation channel and set back about $1.1 \mathrm{~km}$ (0.7 mi). This would make Dogtooth Bend an island in Illinois and turn the current Mississippi River channel between mile markers 34 and 15 into an oxbow lake. Dogtooth Bend Island could be used for floodwater storage during major flooding events since it is 4,800 ha $(12,000 \mathrm{ac})$ in size, which along with thousands more acres in the oxbow lake and other nearby islands and adjacent land not levee-protected within the current mainline federal and farmer levees, would enlarge flood storage capacity in the area. If the new Mississippi River channel is used for navigation, the current Mississippi River shipping channel length would be reduced by 24 $\mathrm{km}$ (15 mi). Landowners would need to be compensated if the Dogtooth Bend area is used for a new Mississippi River channel or for temporary flood storage during the nongrowing season.

Historically, the Mississippi River bottomlands have experienced hundreds of Mississippi River realignment events and course changes in the river. The large number of oxbow remnants and interior old meanders (e.g., nearby Horseshoe Lake area) are evidence of the past and harbingers of the future. Federal, state, and local managers of the Mississippi and Ohio river landscapes can impede or delay the Mississippi River realignment by attempts to maintain the status quo, but realignment will eventually happen. Over time, the mighty Mississippi River will eventually win, as it always has in the past.

\section{CONCLUSIONS}

Prior to the construction of the farmer (Len Small-Fayville) levee in Illinois and the farmer (Commerce to Birds Point) levee in Missouri, the Mississippi River was $16 \mathrm{~km}$ (10 mi) wide between mile markers 39 to 15 (figure 3 ). The creation of 
these two levees restricted the Mississippi River floodplain to less than $2 \mathrm{~km}(1.5 \mathrm{mi})$ and increased the peak height of the river during flooding events that occurred after 1943. The resulting increased river velocity and height place both levees, as well as downstream levees, at risk of failure.

The USACE/MRC mission includes the maintenance of the mainline levees that protect Cairo, Illinois, and the Illinois, Missouri, Kentucky, and Arkansas bottomlands and the maintenance of navigation on the Mississippi River. The USACE cannot strengthen the existing Len SmallFayville levee without increasing the risk of losing their own mainline levees (Cairo levee and floodwall, the Commerce to Birds Point levee and the New Madrid Floodway setback levee). If the Cairo floodwall and levee were to fail, it would put nearly 3,000 residents and 400 structures at risk. If the Commerce to Birds Point levee or the New Madrid Floodway setback levee were to fail, 800,000 ha $(2,000,000 \mathrm{ac})$ in Missouri, Kentucky, and Arkansas bottomlands could be flooded with both crops and soils damaged. The opening of the New Madrid Floodway can be used to reduce the pressure and

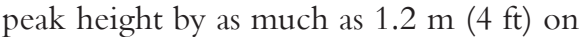
confluence area levees (Olson and Morton 2012). The floodway was used in 1937 and 2011. There is a need for additional floodwater storage in the confluence area of the greater Ohio and Mississippi rivers (Olson and Morton 2016a, 2016b, 2016c). A regional effort on both sides of the Ohio and Mississippi rivers is needed to strategically identify floodplain areas that could provide temporary water storage and policy incentives for landowners of low-lying lands to profitably invest in crops and income alternatives.

Climate scientists predict a continued pattern of extreme rainfall events in the upper Mississippi River region (Olson and Morton 2016c). This suggests that unexpected above-average rainfall events in the Ohio and Mississippi river basins will continue to increase the frequency of extreme flooding events on these great rivers. As the frequency of intense precipitation events increase, the current Illinois and Missouri farmer levee systems are likely to repeatedly fail if repaired to existing height and strength. The current solution to prevent flooding in the Dogtooth Bend area is not working. Combinations of land use changes and new structures are needed to address the problem. Whatever solutions are chosen, there will need to be a significant investment of human and financial resources to prepare for the future.

\section{REFERENCES}

Maruszak, Kathleen. 1977. National Register of Historic Places Inventory/Nomination: Dogtooth Bend Mounds and Village Site. Washington, DC: National Park Service.

Olson, K.R., and L.W. Morton. 2012. The impacts of 2011 induced levee breaches on agricultural lands of Mississippi River Valley. Journal of Soil and Water Conservation 67(1):5A-10A, doi:10.2489/jswc.67.1.5A.

Olson, K.R., and L.W. Morton. 2013. Restoration of 2011 Flood Damaged Birds Point-New Madrid
Floodway. Journal of Soil and Water Conservation 68(1):13A-18A, doi:10.2489/jswc.68.1.13A

Olson, K.R., and L.W. Morton. 2015. Impact of levee breaches, flooding, and land scouring on soil productivity. Journal of Soil and Water Conservation 70(1):5A-11A, doi:10.2489/jswc.70.1.5A.

Olson, K.R., and L.W. Morton. 2016a. Missouri Ozark Plateau Headwaters Diversion engineering feat. Journal of Soil and Water Conservation 71(2):13A-19A, doi:10.2489/jswc.71.1.13A.

Olson, K.R., and L.W. Morton. 2016b. Little River Drainage District conversion of Big Swamp to agricultural land.Journal of Soil and Water Conservation 71(2):37A-43A, doi:10.2489/jswc.71.2.37A.

Olson, K.R., and L.W. Morton. 2016c. Managing Mississippi and Ohio River Landscapes. Ankeny, IA: Soil and Water Conservation Society.

Williams, D.R., B.C. Fitch, and S.J. Indorante. 2007. Soil Survey of Alexander County, Illinois. Washington, DC: USDA Natural Resources Conservation Service. 